11. Popova, G. V. (1997). Professionalnaya komunikativnaya kompetentnost rabotnika OVD [Professional communicative competence of the Internal Affairs Officers] : dis. ... kandidata psikhol. Nauk : 19. 00. 01 / Un-t vnutr. del. Kharkov, 163 s. [in Rus.]

12. Petrovskaya, L. A. (1989) Kompetentnost' v obshchenii : sotsial'no-psikhologicheskiy trening [Communication competence: socio-psychological training]. M. : Izdatel'stvo Moskovskogo universiteta, 216 s. [in Rus.]

\title{
Summary
}

The objective analysis of the activities of pre-trial investigation officers allows us to describe the classes of professional communication situations that require them to have appropriate professional communicative competence.

In the article, we offer the analysis of the «chain» of activities of the National Police employee on the example of the investigator's activity in terms of professional communicative qualities necessary for the professional performance of his professional activity. The main components of these competencies were identified and the specific communication skills of the staff of pre-trial investigation bodies were considered, taking into account the requirements of the present. Much attention is paid to the ability to consciously manage verbal and non-verbal expressions of emotions, to conduct constructive dialogue with both offenders, and with minors (underage people) and other categories of citizens. The article considers the essence of the content of professional communication of investigators, its components, distinguishes specific characteristics of professional communication in the activities of the employees of pretrial investigation bodies. Attention is focused on improving the communicative competence of National Police officers by conducting social and psychological training, which in its turn contributes to the professional skills of the specialists.

Keywords: communicative competence, aggressive environment, communicative skills, minors (underage people), social perception, training.

UDC 372.881 .1

DOI: $10.31733 / 2078-3566-2019-5-302-306$

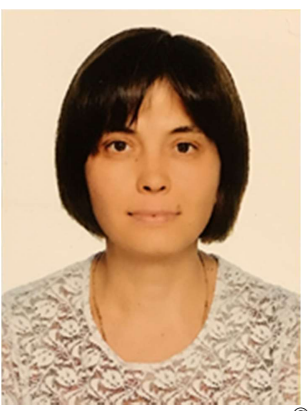

Ganna DEKUSAR ${ }^{\circledR}$

Lecturer

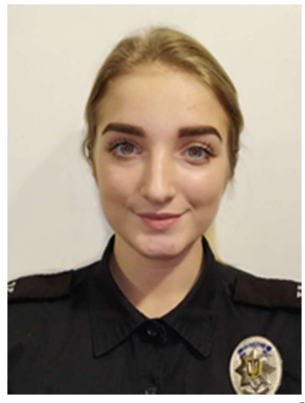

Olena DYSHKANT ${ }^{\odot}$ Cadet

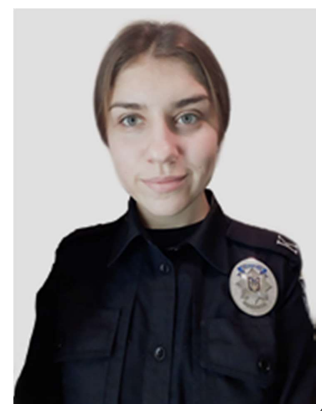

Viktoria DEHTYAR ${ }^{\circledR}$

Cadet

(Dnipropetrovsk State University of Internal Affairs)

\section{USE OF INFORMATION TECHNOLOGIES AS A MEANS OF INCREASING MOTIVATION WHEN LEARNING FOREIGN LANGUAGE IN NON-LINGUISTIC HIGHER EDUCATION INSTITUTIONS}

Ганна Декусар, Олена Дишкант, Вікторія Дегтяр. ВИКОРИСТАННЯ ІНФОРМАЦЙНИХ ТЕХНОЛОГІЙ ЯК ЗАСІБ ПІДВИЩЕННЯ МОТИВАЦІЇ ПРИ ВИВЧЕННІ ІНОЗЕМНОЇ МОВИ У ВИЩИХ НАВЧАЛЬНИХ ЗАКЛАДАХ НЕФІЛОЛОГІЧНОГО ПРОФІЛЮ. Освітні реформи, які проводяться в нашій країні, поряд із розробкою нових освітніх стандартів, зумовили необхідність зміни методики викладання іноземної мови в університетах. Підвищення мотивації студентів, підвищення інформаційної спроможності навчального процесу, застосування та активізація сучасних методів навчання, а також використання нових навчальних посібників та технологій - основні завдання, які стоять

\footnotetext{
(C) Dekusar G., 2019

ORCID iD: https://orcid.org/0000-0001-8727-5944

k_mp@dduvs.in.ua

(C) Dyshkant O., 2019

olenkazelenkadishkant@gmail.com

(C) Dehtyar V., 2019

betavik17@gmail.com
} 
сьогодні перед вищим навчальним закладом.

У статті розглянуто різні підходи вітчизняних та іноземних науковців щодо визначення концепції «мотивації», визначено шляхи підвищення мотивації студентів вищих нелінгвістичних навчальних закладів та окреслено ключові проблеми використання інформаційних технологій при вивченні іноземної мови студентами.

У роботі представлено конкретні приклади успішного використання комп'ютерних технологій при викладанні англійської мови у вищих навчальних закладах нефілологічного профілю, проаналізовано їх переваги та акцентовано увагу на необхідність комплексного підходу щодо їх використання. Наведено приклади інформаційних технологій, які можна ефективно використовувати при викладанні іноземної мови у вищих навчальних закладах: платформа МООDLE, електронні підручники та словники, дистанційні електронні курси, мультимедійні презентації, навчальні комп'ютерні програми, тощо.

У статті підкреслюється можливість поєднання новітніх та традиційних технологій викладання іноземної мови.

Метою статті є доведення доцільності запровадження інформаційних технологій у процесі викладання іноземної мови, що призводить до суттєвого підвищення мотивації у здобувачів вищої освіти.

Ключові слова: мотивація, інформаційні технології, мультимедійна презентація, електронний підручник, дистанційне навчання

Problem statement. The educational reforms that are taking place in our country, along with the development of new educational standards, have also necessitated a change in the methodology of teaching a foreign language in universities. Increasing the motivation of students, increasing the information capacity of the educational process, the application and activation of modern teaching methods, as well as the use of new teaching aids and technologies are the main tasks that the higher education institution is facing today [2, p. 17].

Analysis of publications that started solving this problem. The analysis of motivational factors in the educational process (in particular when learning a foreign language) involved a number of both domestic and foreign researchers, namely: IA Zimnya, SL Rubinstein, AK Leontiev, NM Simonova, M. Rost, K. Ames, K. Williams, T. Bell, and others. The problem of motivation in learning a foreign language, according to M. Rost, is the most important, before which the problems of the methodology of teaching [7]. And in fact, problems in motivation arise at least because: 1) there is no great opportunity to involve students in a foreign language environment; 2) there is not a sufficient number of native speakers to communicate with. Thus, the student must have simply extraordinary internal and external motivation to learn a foreign language. Not for nothing K. Ames [5] quotes T. Bell's quote: "There are three things you need to remember in education. The first thing is motivation. The second thing is motivation. The third is motivation. Researchers who study motivation define it as goaloriented. This orientation can be positive, negative, or ambivalent (dual). K. Williams [6] identifies five major components to enhance student motivation: student, teacher, content, method / process, environment. This problem is investigated in the framework of the activity approach to learning, developed by SL Rubinstein. AK Leontiev [4] and others. In the field of foreign language teaching, psychological issues of motivation are addressed in the works of AA Alkhazishvili, IA Winter, AA Leontiev, NM Simonov, and others. According to IA Winter [3], "a motive is what explains the nature of a given linguistic action, whereas a communicative intention expresses what communicative purpose is pursued by the speaker, planning some form of influence on the listener."

The article's objective is to substantiate the feasibility of introducing information technologies into the foreign language teaching process by substantially increasing the motivation of higher education applicants.

Basic content. The proliferation of English, the increasing number of English language learners, have led to the emergence of different teaching methods and technologies. The advent of information technology has radically changed the nature of foreign language teaching at a non-linguistic university, making the learning process more exciting and productive.

The most commonly used elements of information technology in the educational process are: electronic textbooks and tutorials that are demonstrated by a computer; multimedia projector; interactive whiteboards; electronic encyclopedias and reference books; testing programs, educational resources of the Internet; distance learning materials; projects and presentations. Studying English with the use of information technologies in our university gives students the opportunity to participate in open classes using multimedia, conferences, olympiads, boundary and exam testing, study remotely, etc. Classical and integrated classes, accompanied 
by multimedia presentations, online tests and software, allow students to gain knowledge in a more productive way, as they say in the English saying: "Tell me - I'll forget, show me - I'll remember." I would like to focus on the most commonly used information technology lessons in foreign language classes.

A computer lesson developed by Power Point is a thematically and logically related sequence of information objects displayed on a screen or monitor. Various informational objects are used during the lesson: images (slides), audio and video clips. The performance of slides, images and other demonstration materials will be much higher if complemented by the display of diagrams, tables. After such lessons, the material studied remains in the memory of students as a vivid image and helps the teacher to stimulate their motivation. Most often, non-linguistic universities have combined-type classes where both homework surveys and explanations of new material are present. The Power Point Presentation Program combines a variety of visuals, maximizing the benefits of each and eliminating the disadvantages.

Creating and using multimedia presentations in Microsoft PowerPoint is an effective way of teaching that helps the student to become aware of an active subject.

Using a computer presentation in class allows you to: 1) apply a large amount of illustrative material, creating striking spectacular patterns in the form of diagrams, diagrams, graphic compositions, etc.; 2) intensify classes by eliminating the time to write material on the board; 3) involve students in an independent learning process, which is especially important for the development of their general education skills; 4) to focus students' attention on the important points of teaching information; 5) affect several types of memory: visual, auditory, emotional and in some cases motor. You can use a presentation in the educational process at different stages of the lesson, with its essence as a visual means remains unchanged, only its forms change, depending on the intended purpose of its use.

I think it is advisable to use a computer training program in English, "Tell me more," in practical English classes. This program can be used for classroom, individual or independent work of students. Exercises are aimed at developing all kinds of language activities. Particular attention is paid to listening as one of the most difficult skills in learning a foreign language. Types of exercises are presented, such as: exercises for listening and checking the content of the audio recorded; exercises for the formation of graphic and sound image of the word through the activation of new lexical units; exercises on the formation of skills of reading and training in use; letter matching method; the method of perceiving a word or phrase as a unit; finding the word on the screen by its sound; exercises on semanticization of vocabulary and development of spelling literacy; exercises for forming grammatical skills. Higher education students are very happy to take such classes, repeat words, watch movies and perform exercises. The ability to listen to the recording several times, repeatedly perform the task gives students confidence in their abilities and increases their self-esteem. Because a lot of attention is paid to listening, students get used to listening to a foreign language and the language becomes "live". The use of information technology helps to make the lessons more memorable, interesting, and memorable.

An important aspect of using information technology in English is project activity. Multimedia presentations have been actively involved in the learning process. Higher education providers use the Internet to collect material for their projects. Studying a topic or section always ends with repetition, consolidation, and generalization. All these elements can be combined by inviting cadets to create a multimedia project after each topic is completed. When creating a presentation, they are given a great opportunity to organize their knowledge and skills. It is very important to give them a sense of interest in independent creative work, to evaluate the significance of the results of their work, since the presentation is a ready methodical material for the lesson. It should be noted that every year, applicants learn to make presentations in a better quality, professionally, with great interest, feeling their success and improving their skills. In particular, at the Dnipropetrovsk State University of Internal Affairs (DGSD), cadets of 1-2 courses studying at the Faculty of Economic and Legal Security, during the work on the topic "Types of crimes", presentations were prepared on such topics as: "Classification of crimes according to severity", "Types and classification of methods of combating crime", "Types of drug offenses", etc.

The project activity of higher education applicants using presentation has several positive aspects: 1. First, students' independent creative work in creating computer presentations maximizes the supply of active foreign language vocabulary; 2 . Secondly, creating a presenta- 
tion increases the level of proficiency in English and the computer; 3. And, most importantly, this type of work shapes the student's self-activity skills and initiative, as he determines what the presentation will be, specifically, in what form and how it will pass. Thus, we can conclude that the presentation is an opportunity for students to express their ideas in a creatively thought out and convenient way for them.

The Dnipropetrovsk State University of Internal Affairs also provides training in the use of distance learning technologies in the field of foreign language training on the MOODLE platform. Distance learning has several advantages: it is distance learning, which is organized with the help of modern information technologies; this is an opportunity to work independently with educational computer training materials; this is the prospect of higher education without a break from production and at a convenient time for the student; it is an opportunity to take exams and tests, to participate in online seminars, trainings, to receive individual consultations without leaving home. E-learning complexes have been developed for distance learning students, which include instructional video lectures, texts, exercises, self-control questions, a glossary of terms in the discipline under study, as well as an index of links to online resources where you can gain additional knowledge on throughout the disciplines of the curriculum chosen by the student specialty. All that is needed for a distance learning student is a Windows computer and Internet access. There are no age, professional, educational restrictions when teaching with the use of distance education technologies. Students can get a college degree without leaving their residency, study subjects, take credits and take exams from the Internet. After successful study, a diploma of higher education of the state model is issued.

The introduction of electronic textbooks in the educational process of our university has a number of advantages, first, it is their mobility, secondly, the accessibility of communication with the development of computer networks, and third, the adequacy of the level of development of modern scientific knowledge. On the other hand, the creation of electronic textbooks also contributes to the solution of such problems as constant updating of information material. They can contain a large number of exercises and examples, detailing the dynamics of different types of information. In addition, electronic textbooks control knowledge - computer testing. The possibilities of using Internet resources are enormous. The Global Internet creates the conditions for receiving any information and information needed by students and teachers from anywhere on the globe: news, country material, and more. In foreign language classes, the Internet helps to solve a number of didactic tasks: to develop reading skills and skills, using the materials of the global network; improve students' writing skills; replenish their vocabulary; to form a strong motivation for students to learn English. In addition, the work is aimed at exploring the possibilities of Internet technologies to broaden the students' outlook, maintain business contacts and contact with their peers in English - speaking countries.

Using electronic dictionaries is another example of the introduction of computer technology when learning a foreign language. It combines the functions of finding the right information, demonstrating linguistic patterns, and makes it possible to learn training material through a special system of exercises. All modern electronic dictionaries use the audio features of multimedia personal computers to reproduce pronunciation. Most often, students use the following dictionaries: Google, Promt (translates sentences from Ukrainian to English and from English to Ukrainian); on-line Multitran Dictionary (the new edition contains about 160,000 words). To translate using any of these dictionaries, you must enter a word or phrase in the dialog of the selected dictionary and follow the instructions in the electronic dictionary. The use of electronic online dictionaries is especially convenient when you need to translate more than one dictionary unit, but several, for example, when working with "keywords" of text, dialogue, etc., when performing reading training exercises in the pre-textual stage. And of course, the ability to use almost any dictionary online saves time and effort.

Conclusions. It should be emphasized that the introduction into the educational process of information technology does not exclude traditional methods of teaching, but harmoniously combines with them at all stages of learning. The use of new technologies not only repeatedly increases the effectiveness of learning, but also encourages students to further learn a foreign language.

Various computer and multimedia programs and their development allow attracting visual, audio and kinesthetic channels of information assimilation, which is especially relevant for teenagers, since in this period of study the kinesthetic method of information perception is the most effective [3]. Inattentive students are better able to perceive the information presented on 
the screen, which allows them to develop and actualize their imagination, as well as to absorb material without difficulty. Those who learn to exercise their autonomy, cooperate with each other and with the teacher, develop communicative qualities, which increases the motivation and activates the cognitive activity of higher education applicants.

Thus, the use of computer technology in foreign language classes at universities is dramatically changing the learning environment. In the center of learning, he finds himself the educator - his motives, goals, his psychological features, and the teacher in this case acts only as an assistant, which leads to the activation of students' mental activity, which forms a positive motivation for these activities [4].

\section{References:}

1. Антонова Н. В., Шмелева Ж. Н. Формирование коммуникативной компетенции при изучении английского языка студентами неязыкового вуза. Вестн. КрасГАУ. - 2014. - № 2. - С. 240-244.

2. Захарова И.Г. Информационные технологии в образовании: Учеб. пособие для студентов педагогических вузов. - М.: Академия, 2006.

3. Зимняя И.А. Психологические аспекты обучения говорению на иностранном языке, Москва «Просвещение», 1978 г.

4. Леонтьев А.Н. Обучение как проблема психологии // Вопросы психологии, 1957, № 1, c. $3-17$.

5. Carol A. Ames. What teachers need to know [электронный ресурс] Режим доступа: http://www.unco.edu/cebs/psychology/kevinpugh/motivation_project/resources/ames90.pdf

6. Caroline C. Williams. Five key ingredients for improving student motivation. California State University, Stanislaus Caroline C. Williams University of Wisconsin, Madison [электронный ресурс] Режим доступа: www.aabri.co.manuscripts/11834

7. Michael Rost. Generating Student Motivation. Michael Rost Series Editor of World View [электронный ресурс] - Режим доступа: www.longman.com/worldview

Received to editorial office 09.12.2019

1. Antonova, N.V. and Shmeleva, Zh.N. (2014). Formirovaniye kommunikativnoy kompetentsii pri izuchenii angliyskogo yazyka studentami neyazykovogo vuza [The formation of communicative competence in the study of English by students of a non-linguistic university] : Vestn. KrasGAU. № 2, S. 240244. [in Russ.]

2. Zakharova, I.G. (2006). Informatsionnyye tekhnologii v obrazovanii: Ucheb. posobiye dlya studentov pedagogicheskikh vuzov [Information technology in education. Textbook for students of pedagogical universities] : M. : Akademiya. [in Russ.]

3. Zimnyaya, I.A. (1978). Psikhologicheskiye aspekty obucheniya govoreniyu na inostrannom yazyke [Psychological aspects of teaching English speaking] : Moskva «Prosveshcheniye». [in Russ.]

4. Leont'yev, A.N. (1957). Obucheniye kak problema psikhologii [Education as a problem of psychology] : Voprosy psikhologii, № 1, s. 3-17. [in Russ.]

5. Carol, A. Ames. What teachers need to know [Electronic resource] - URL: http://www.unco.edu/cebs/psychology/kevinpugh/motivation_project/resources/ames90.pdf [in Eng.]

6. Caroline C. Williams. Five key ingredients for improving student motivation. California State University, Stanislaus Caroline C. Williams University of Wisconsin, Madison [Electronic resource] URL: www.aabri.co.manuscripts/11834 [in Eng.]

7. Rost, M. Generating Student Motivation. Michael Rost Series Editor of World View [Electronic resource] - URL: www.longman.com/worldview [in Eng.]

\section{Summary}

Different approaches of domestic and foreign scholars to define the concept of "motivation" are considered, ways of increasing the motivation of students of non-linguistic higher education institutions and topical issues of using information technologies in the study of a foreign language are singled out. Specific examples of information technologies for teaching English in non-linguistic higher education institutions that are already successfully applied in practice are presented, their advantages are analyzed and the need for a comprehensive approach to their use is emphasized.

The purpose of the article is to substantiate the feasibility of information technologies introduction in the process of teaching a foreign language by significantly increasing the motivation of higher education applicants.

Keywords: motivation, information technologies, multimedia presentation, e-textbook, distance learning. 